\title{
THE ADVANTAGES OF BEING A MEMBER OF THE EUROPEAN MONETARY UNION AND ITS INFLUENCE ON TRADE IN THE EUROZONE
}

\author{
Milica Stankovic", Higher School of Professional Business Studies, Novi Sad
}

\begin{abstract}
The European Monetary Union is of great importance for its member states, since being its part implies a lot of privileges. One of them is transaction costs reduction due to the elimination of currency exchange. Lower transaction costs enable easier and much more profitable trade between Member States of the European Monetary Union. The most notable achievement of the European Monetary Union is the single currency - the euro which becomes frequently used today in the international trade. A significant benefit is an elimination of foreign exchange risks since it influences reinforcement of internal market and reduces investment risks. Price transparency in trade between two Member States and within them, leads to the price homogenisation in the EU. This work examines and analyses the advantages of being the part of the European Monetary Union, with a particular attention paid to its influence on trade in the Eurozone.
\end{abstract}

Key words: European Monetary Union, trade, advantages, euro, integration, exchange rate, Eurozone, single market

JEL classification: F10, F13, F33

\section{PREDNOSTI ČLANSTVA U EVROPSKOJ MONETARNOJ UNIJI I UTICAJ NA TRGOVINU U EVROZONI}

Sažetak: Evropska monetarna unija je od velikog značaja, s obzirom da podrazumeva integrisanje velikog broja država koje članstvom u uniji ostvaruju niz prednosti. Jedna od prednosti je smanjenje transakcionih troškova usled eliminisanja potrebe za konverzijom valuta. Manji transakcioni troškovi čine mnogo lakšom i profitabilnijom trgovinu između zemalja članica Evropske monetarne unije. Najzapaženije dostignuće Evropske monetarne unije je jedinstvena valuta- evro koja se danas sve više koristi u međunarodnoj trgovini. Eliminacija rizika deviznog kursa je značajna prednost $s$ obzirom da utiče na jačanje unutrašnjeg tržišta $i$ smanjenje rizika investiranja. Transparentnost cena u trgovini između država članica i unutar država članica dovodi

\footnotetext{
*milica.stankovic.vps@gmail.com
} 
31 | THE ADVANTAGES OF BEING A MEMBER OF THE EUROPEAN MONETARY UNION AND ITS INFLUENCE ON TRADE IN THE EUROZONE

do homogenizacije cena $u$ EU. $U$ radu se akcenat stavlja na prednosti koje se obezbeđuju članstvom u Evropskoj monetarnoj uniji, sa posebnim osvrtom na uticaj na trgovinu u Evrozoni.

Ključne reči: Evropska monetarna unija, trgovina, prednosti, evro, integracija, devizni kurs, Evrozona, jedinstveno tržište

\section{INTRODUCTION}

The European Monetary Union is in fact only one part of a grand vision of an integrated Europe. The Formation of the European Monetary Union has been a long process of an immense historical significance. Signing the Paris and Rome conventions, European leaders have founded the European Union's legal basis. Since then, Europe has advanced significantly. One of the most significant achievement is the establishment of common market, including free movement of people, goods, and capital. Afterwards, the European Monetary Union was formed, which at its beginning had 11 Member States, but now it has 17 Member States. The European Monetary Union implies changes within the system of different national currencies into the single European currency (the euro), with separated National Central Banks, and with separated National Monetary policies altogether with a single European system of Central Banks, and single European Monetary policy. The adoption of the single currency is one of the most courageous attempts ever done, so that big and diverse group of sovereign states could earn a variety of profit using the single currency. In this paper one can find out more about the establishment of the European Monetary Union, and also about the advantages of being its member. Considering positive correlation between introducing the single currency and integrated trade, the effect which is specially emphasized is what The European Monetary Union (EMU) membership implication has on trade in the Eurozone.

\section{THE DEVELOPMENT OF THE EUROPEAN MONETARY UNION}

A Monetary Union is said to be the maximum of European integration. The European monetary union is said to be a very big experiment. This is why it is interesting to discuss about its history, relevance, and future (van Veen, 2002). The contract of forming the European Economic Union did not imply the organisation of the European Monetary Union. A Monetary union would imply irreversible convertability of currencies, elimination of fluctuations in exchange, and irrevocable fixation of exchange rate, as well as a complete liberalisation of capital movements. A Monetary Union can be seen as a zone in which economic goals are reached through mutual monetary policy and currency rate 
(Memišević, 2010). In 1962, for the frist time, the motion of forming the European monetary union was prompt. The EU Member States' attempt of deepening the integration was affirmed at the EU summit of leaders in the Hague in 1969. Werner's document is one of the three most important documents that have helped the establishment of the European monetary Union, while the other two being the Delors Report and the Maastricht Treaty. Werner's document (1971) nominated the formation of the European Monetary Union in three phases. The first phase would be ensuring a higher level of economic integration between the EU Member States. The second phase would be the irreversible convertibility of currencies. Finally, the third phase would be the permanent locking of exchange rates - or possibly the single currency (Miljković, 2008). In 1972, the zone of mutual fluctuation of six currencies was introduced. Currency fluctuations had to be contained within a margin of $2.25 \%$ on either side of the bilateral rates. This mechanism was called "snake in the tunnel". However, this mechanism did not work, so in 1979, the decision of forming the European Monetary System was brought. The European Exchange Rate Mechanism (ERM) was a system introduced by the European Community in 1979, in order to reduce exchange rate variability. At the same time monetary currency was introduced, named the European Currency Unit (ECU). In 1989, the Delors Report proposed the new attempt of monetary integration (Džombić, 2010). The establishment of the European monetary union represents the abolition of national currencies, substituting them with the single currency.

The main support for further integration towards the European monetary Union, with one Central Bank, and the single currency is the EU single internal market. The European Monetary Union is a union of several sovereign states, that have reached a consensus on the single currency, and on the single monetary policy, but which have not reached the consensus on mutual fiscal policy (Siklos, 2009). Today, 17 countries are members of the European Monetary Union: Austria, Belgium, Cyprus, Estonia, Finland, France, Germany, Greece, Ireland, Italy, Luxembourg, Malta, Netherlands, Portugal, Slovakia, Slovenia, Spain. The three other countries which do not want to become a part of the Eurozone are: The United Kingdom, Denmark, Sweden . Other member states are in different phases of entering the eurozone, but it is expected of them to become its part in ten years time. In particular, it may be a route toward an independent monetary policy, which alleviates the scope for political pressure to relax monetary policy (Beetsma, \& Giuliodori, 2010).

There are two postulates of adopting the euro. The first one is that the EU member states should be economically compatible with the single currency. The second one is that the EU should have a mechanism to protect the purchasing power of the single currency (Zirojevic, \& Jelisavac, 2002). On January 1, 2002, the new European currency, the euro, became official in 11 
countries, known as the eurozone. Today, euro is used as the single currency in 17 member states of the European Monetary Union. There is a considerable amount of authors, who have been supporting the use of euro as the single currency, on the contrary there is a small number of those authors who have been sceptical about it. Economists point out that the economy and finances of the EU member states could cause the fall of the European Monetary Union. The currency had performed well until a global economic downturn which began in 2008. In general, countries worldwide suffered badly. In particular, the Eurozone members with weaker economies struggled to repay their debts, which damaged confidence in the Euro. The situation in the Eurozone worsened in 2010, when Greece suffered a financial crisis. After a concern that other weak Eurozone economies would face similar crisis, the European Financial Stability Facility (EFSF) was created to provide loans to struggling Eurozone states.

\section{THE ADVANTAGES OF BEING A MEMBER OF THE EUROPEAN MONETARY UNION}

If we take the long view, it is sure that the European Monetary Union will prove to be very useful, not only for Europe, but also for the entire world. The advantages of being its part are most useful for companies that are also financial and trade partners with European countries. This companies won't have to worry about exchange rate movement nor about commission rates. It can be deduced that being a member of the European Monetary Union would bring a lot of advantages to Pan-European companies (Neu, 2000). However there are a few reasons to question the large number of advantages. Advantages as well as disadvantages of being a part of the European Monetary Union can have both economic and non-economic factors. Non-economic factors include: psychological and political advantages and disadvantages. The psychological advantages due to stability of domestic currency are a higher self-respect, and emphasised national identity. For those, who find political integration desirable, a Monetary Union could be a step closer to the political union. Potential advantages of being a member of Monetary Union can be classified in two groups: micro-economic and macro-economic advantages. Micro-economic advantages include: the enhancement of micro-economic efficiency, the elimination of transaction costs, elimination of exchange rate fluctuations, an increase in foreign trade, effective capital allocation, increasing competition, and price transparency. Macro-economic advantages include: elimination of problems that can arise from foreign currency instability, and low inflation due to independent European Central Bank, and having euro as the single currency (Kotilainen, 1992). 


\subsection{Transaction cost reduction}

Along with the elimination of the need to exchange currencies, transaction costs reduced. Transaction cost reduction can be seen through visible and invisible savings. Visible savings are household and company savings due to the reduction in transaction costs, associated with the exchange of currency by firms that import or export. Invisible savings are obtained in the accountancy, because the evaluation of financial report positions is done in one currency. It should be pointed out that the omission of exchange rate fluctuations narrows possible misuse in the acountancy. Eliminating exchange rate flutuations contributes to the objective and fair financial report. Due to the introduction of euro as the single currency instead of different number of national currencies, transaction cost reduction relates to reduction of direct costs of exchange and lower accountancy costs for corporative sector. Transaction costs are eliminated in the eurozone, so the citizens of the EMU members are allowed to travel at low costs, no matter what the purpose of their trip is (for instance, to study or to work). The single currency means that travellers would not have to convert their money as they travel from one country to another, nor they should pay currency rate. As there exists a single currency, people won't need to exchange currency in order to buy or sell while being in another country. Tourists are the ones who are the most exposed to transaction costs. By introducing the single currency, tourists would not have to exchange currency wherever they go, or search for an exchange office or a bank, that charge at a low commission. Companies that make a deal outside their borders, but within the eurozone can plan ahead their business, and they do not have to worry about the Value Added Tax (VAT) on purchasing power, because of exchange rate fluctuation in the eurozone. Companies have achieved a lot of gain because of the elimination of the need to exchange currencies between the EMU members. By switching to the euro, members of the EMU were expected to save as much as $\$ 30$ billion a year (Eudey, 1998). In addition to this, maintaining the single currency is more profitable. Along with eliminating the need to exchange currencies, the problem with exchange rate fluctuation is also eliminated within the EMU members. It implies that the exchange rate fluctuation would exist only between the euro, yen, dollar, and other national currencies outside the EMU members. In the upcoming period the remarkable technological innovations will cause the reduction of financial transations costs.

\subsection{The euro as an international currency}

The most remarkable achievement of the EMU is the euro which ensures stability of companies, national economy, and limits international currency speculation. Today, the euro is used as an international currency. The introduction of the euro made a serious impact on the dollar, yen, pound, and 
other currencies, because their value reduces on a global level. Using dollar as an international currency, enables the USA to achieve gain of approximately 1015 billion dollars. The expectations, before introducing the euro, were that it would bring a lot more gain to the EU. The euro is the most used currency in the eurozone, and it gradually replaces dollar in the international trade. It helped Amsterdam and Frankfurt to become opponent to New York, which is said to be the Finance Center. This advantage would have been greater had the UK become a part of the EMU, since London is a trustworthy rival to New York (Dunn, 1999). The main importance of the euro reflects in its role as an international investment, reserve and trading currency in countries, which are not EMU members, which even tie their currencies to the euro and conduct international invoicing in euro. Although euro became international currency it falls behind dollar in terms of global reserves, and international invoicing (Cooper, \& Tomić, 2007). Introducing the euro means that the group of sovereign countries voluntarely gave up their national currencies in favor of a common currency. Because of that, the euro is seen as the major economic matter. Europe is said to have created euro in order to make an integrated market like the USA (Salvatore, 2009). Introducing the single currency has both costs and benefits. A rough parallel can be drawn between the costs and benefits of the euro, and the costs and benefits of being a member of the EMU.

According to Eurobarometer survey, the euro constantly has a clear support of people who use it. In 2007, the majority of $71 \%$ member states voted for the euro, while $21 \%$ voted against the euro. The Euro is considered to be one of the most tangible benefits of European integration. According to the EU population, the leading positon of the euro's benefits is the freedom of travelling easily across the border, in order to work or study (European Commission, Economic and Financial Affairs, Economic and Monetary Union). Today, the euro becomes much more used as a reserve currency in foreign countries. As we can see, approximately $25 \%$ of global reserves is saved in euros, comparing to ten years time, when it was only 17\%. Euro is also used as a referential currency for about 40 countries, especially in those countries, which have special insitutional arrangements with the EU, for example, the candidate members. A lot of people outside the eurozone use the euro as a parallel currency, for example, for their savings. This usage is estimated at 70 billons of euros. All new member states will adopt the euro, when the proper time comes, and so they will widen the eurozone, and its significance.

If all 27 countries functioned in the Eurozone, the Eurozone would accomplish priority over the USA not only in terms of population (The EU 27-498,4 million, the USA-304,5 million) but also in terms of taking part in global GDP ( the EU-34,5\%, the USA-28,2\%). The euro's role will grow due to the development and further integration of financial market. Currency's global role 
is the important factor that determines its use by foreign investors (MuchaLeszko, \& Kakol, 2009). A country's strength reflects in its currency appreciation and its currency global effect. It can be concluded that the stability and strength of the EMU depends on stability and value of the single currencythe euro. A stable currency provides stable commission rates and bigger investments. It also provides safety for its companies. Certitude implies guaranteed prices during the currency exchange, which contributes to larger trade size. The stability of the euro stimulates trade between countries within the Eurozone and the rest of the world. The Euro, as the common currency in the EMU, made member states to react coordinately on the global economic crisis, and it also ensured bigger stability, that was almost impossible to be done in the crisis conditions (European Union, Economic and monetary affairs).

\subsection{Reducing the risk of exchange rate fluctuation}

Flexible exchange rates can cause risks in the international trade, and in the international investments. Because of variability and incertitude of exchange rates, econometric analysis are lingered. In period of empirical surveys, exchange rate of one country can be flat, without visible changes, but despite that there can be a huge amount of incertitude about future currency value. A large number of opinion poll asserts the aversion of exchange rate risk that contractors and investors have. Some claim that the exchange rate risk do not actually stop with flat currency transition, yet the risk occurs in quite another form, for example, as a bigger risk than the risk of exchange rate. However, it can be said that this is clearly speculative opinion, since the empirical surveys that support these aspects do not exist. On the contrary, there exist the empirical surveys that show how in the EMU the flat currency transition eliminates the risk of exchange rates. Exchange rate fluctuations make trade between companies from different countries more risky. If one currency value drops in relation to another, then the producer will receive a much smaller amount of money for his product than s/he should have had, or the importer might pay a greater amount of money than arranged. Eliminating the risk of exchange rate fluctuation will help international trade, by giving the advantage to all EMU member states. The risk of exchange rate fluctuation at foreign investment income is removed with the introduction of the single currency. By removing different number of currencies, the important obstacle to direct foreign investment income is eliminated.

Every trade between countries, which do not share a common currency, includes some incertitude of exchange rate risk. Therefore, the chance of exchange rate fluctuation always exists. This chance can affect the profit, investments, competitiveness, as well as customers' decisions. The greatest advantage of adopting the single currency is an elimination of the incertitude of 
currency rate, and the euro as the single currency stimulates the growth of international trade between two countries (Euro Economics, Costs and Benefits of Joining a Monetary Union).

The exchange rate risk contributes to the trade in both directions, which means that it contributes to reduction of one country's imports and exports (Tavlas, 2004). Eliminating the exchange rate instability is highly important, because it can affect both the trade and the investments. The EMU is supported by an independent Central bank, which is focussed on inflation rate reduction and on further monetary integration. The independent European Central Bank is needed, because of instability of financial flows. The introduction of the single currency had an immense effect on capital flow and on EMU member states' profitability (Stanek, 2001). Therefore, the elimination of the instability of exchange rate currency within the EMU, had significantly affected not only the reinforcement of internal market and reduction of investment risk, but also the stimulation of foreign direct investments. This will inevitably stimulate bigger economic union. Smaller countries are more submissive to exchange rate fluctuations. These countries import and export more than bigger countries. The changes of imports and exports that usually happen in smaller countries cause big exchange rate fluctuations. Joining the EMU, effectively magnifies economic quantity of a small country. Fixed exchange rate contributes to bigger discipline in managing economic policies of EMU member states. Actually, states can not use the exchange rate as an instrument with which they would, from time to time, stimulate their national currencies (Perry, 1994). The certitude for those, who export products or perform the business within the EU, is a lot more bigger, because the exchange rate fluctuations can not affect their transactions. By eliminating the exchange rate risk, the relative price instability among the EMU member states will be gradually reduced and eliminated.

\subsection{Increased price transparency}

The EMU has introduced a higher level of transparency in trade among member states, and within them. The price transparency contributes to the price homogenisation in the EU, that results in overall reduction of price level. The reduction of relative price variabilty should stimulate trade within the EMU and further integration of commodities market and services and also it should promote economic efficiency within the eurozone. The price transparency contributes to more intensive competitiveness. If we take the long view, , it will result in a single market higher efficiency, which will further cause low prices for users, and a higher level of competitiveness among European companies globally. In the past it was a commonplace that European companies put different prices for the same products in different parts of the EU, because the prices were expressed in different currencies. The single currency made prices 
flat and more universal. Price transparency, obviously is a huge benefit for its consumers. European consumers are able to compare commodity prices and to decide about its supply, according to its quality and price. Price harmonisation and healthy competition will be improved through enlarged use of PC, which further underlines an enlarged range of Internet trade. The possibility of comparing products will increase with the introduction of the single currency. For the companies this is not a happy solution, because they would have to devise a creative promotion and marketing campaign if they want to secure price differentiability (Stanek, 2001). Bigger price transparency contributes to a bigger competitiveness and low prices. Having the single currency makes easier to compare commodity prices in two different countries (Euro Economics, Costs and Benefits of Joining a Monetary Union).

Introducing the euro made European single market more efficient, enabling sellers from different countries to compete in different areas. With prices, expressed in euro in 17 countries, consumers can find the best possible offer, without calculating variable exchange rates, or costs for conversion services. Additional competition, implied by price transparency keeps prices low within the eurozone, helping prevention of huge price increase, and, in some cases, helps the prevention of price conversion. Not only did the euro enable competition to become increased, and the market to become more integrated, but it also enabled companies to achieve some benefits in economic range. As the commodity prices are expressed in euro, it will contribute to currency appreciation, and at the same time it will contribute to the EU boom. Therefore, the introduction of the single currency will improve economic development, and increase employment (Zirojević et al., 2002).

\subsection{Single market}

The surveys show, that the positive correlation exists between the introduction of a common currency and trade integrations since having a national currency has been cosidered as a trade obstacle. According to this, the single currency and common monetary policy exclude further competition devaluations, make foreign direct investements easier, and help the development of long-term business deals, and also they can abet some forms of political integrations. These results would promote reciprocal trade, economic and social integration and business cycle convergence within the economies that use common currency. Empirical surveys show that the euro will cause an increase in trade within the EMU member states for more than 50\% (Tavlas, 2004). The EMU brings more efficient capital allocation and works through efficient functioning of a single market. The result of that is more competitive European economy. The Eurozone is said to be the biggest trade power in the world. Having common currency instead of different number of national currencies, eliminates 
39 | THE ADVANTAGES OF BEING A MEMBER OF THE EUROPEAN MONETARY UNION AND ITS INFLUENCE ON TRADE IN THE EUROZONE

market segmentations and reduces the size of price discrimination. The before mentioned facts increase efficiency and enable the consumers to gain some profit. The introduction of the euro has increased trade within the Eurozone for $5-15 \%$ since 2009.

\subsection{Preventing competitive devaluation and speculation}

Competitive devaluation implies that a country devalues its currency in order to export more commodities. As a response to this, trade partners would make the same move, which resulted in inflationary spiral in terms of currency value, as well as in increased inflation. Since the EMU goal has been to retain the inflation rates at a low level, the introduction of the single currency makes sense. The single currency would eliminate speculation within the EMU member states. Speculations happened usually within Europe, because whenever people had thought that the currency value was about to decrease, they would sell all their possessions in that currency. High commission rates hindered trade. With elimination of speculations, the EMU member states economies were able to develop faster than they could before, when artificially high commission rates were needed for speculations' defence (The University of North Carolina, The Costs and Benefits of the Euro In European Monetary Union Countries). It is not possible anymore that one EMU member state devaluates its currency in relation to other member states, so as to achieve a price priority on the export market.Now when the devaluation is impossible, bigger credibility of fiscal policy becomes more secured.

\section{CURRENT ECONOMIC TRENDS IN THE EUROPEAN MONETARY UNION}

The global economic crisis had a significant impact on the functioning of the euro area. There are questions about the rules of functioning of the euro area, the future of the EMU, the status of the countries affected by the fiscal crisis, the legitimacy of the monetary union that includes countries with different levels of development and the degree of financial discipline, as well as the legitimacy of further enlargement of the euro zone. According to Angela Merkel, German Federal Chancellor : "The euro, which together with the single market is the foundation for growth and prosperity - also in Germany - is in danger. If we don't deal with this danger, then the consequences in Europe are incalculable, and the consequences beyond Europe are incalculable too . . . because if the euro fails, then Europe fails. But if we do deal with this danger, the euro and Europe will be stronger than before." (Issing, 2011). The global financial and economic crisis has contributed most to the fiscal problems of the EMU member countries which are called PIIGS (Portugal, Ireland, Italy, Greece and Spain). The dramatic increase in the public deficit and debt has made 
investors reluctant to make new loans because they are afraid of bankruptcy, especially in the case of Greece. If it comes to collapse of the EMU, the current crisis could be difficult because the German, French and other banks that hold much of the debt of Greece could run into significant problems. So, in the interest of other members of the EMU is to help Greece. The crisis that began in Greece culminated in the crisis of the euro area as a whole. There is no doubt that the main responsibility is on Greek authorities. The solution to this problem will require drastic changes in the Greek economy and fiscal policy. Financial markets and the euro area authorities also bear some responsibility for the transformation of the Greek crisis in the systemic crisis in the eurozone (De Grauwe, 2010). If each member state acts according to its own will and not according to the common rules, it will provide the opportunity for the disintegration of the EMU to come. Not only Greece, but also other states may alike face bankruptcy. It would not be fair to Germany and several other EMU countries that would have to pay the bill. Poor management of EMU could harm the competitiveness of all EMU countries. The big challenge now is to fully enforce regulations that make the EMU sustainable in the long run (Kosters, 2010).

Table 1 shows the state of the public finances and indicates worrying increase in public debt in most of the EMU countries. Public debt as a percentage of GDP is over $100 \%$ in Italy and Greece. The annual balances presented in Table 2 show how governments manage their current budgets. In Greece, the budget deficit is higher than 3\% each year in the period from 1999 to 2010. One look at the numbers is enough to show that the Stability Pact has failed to justify its name over the years. The criteria that the debt of a Member State must not exceed $60 \%$ of GDP apparently never was taken seriously. The data in Table 3 show an increase in unit labor costs and indicates the conclusion that this area is not less worrying than the state of public finances. Unit labor costs continued to diverge across countries. The same goes for inflation rates. As might be expected, there are differences between countries that are reflected in the balance of payments- surplus and deficit (Table 4). Accordingly, the elimination of such differences is difficult and requires years of fiscal discipline (Issing, 2011). 
41 | THE ADVANTAGES OF BEING A MEMBER OF THE EUROPEAN MONETARY UNION AND ITS INFLUENCE ON TRADE IN THE EUROZONE

Table 1

Government gross debt (as \% of GDP) in the euro area countries

\begin{tabular}{lrrrrrrrrrrrr}
\hline & 1999 & 2000 & 2001 & 2002 & 2003 & 2004 & 2005 & 2006 & 2007 & 2008 & 2009 & EC 2010 \\
\hline Belgium & 113.7 & 107.9 & 106.6 & 103.5 & 98.5 & 94.2 & 92.1 & 88.1 & 84.2 & 89.6 & 96.2 & 98.6 \\
Germany & 60.9 & 59.7 & 58.8 & 60.4 & 63.9 & 65.8 & 68.0 & 67.6 & 64.9 & 66.3 & 73.4 & 75.7 \\
Estonia & 6.0 & 5.1 & 4.8 & 5.7 & 5.6 & 5.0 & 4.6 & 4.4 & 3.7 & 4.6 & 7.2 & 8.0 \\
Ireland & 48.5 & 37.8 & 35.5 & 32.1 & 30.9 & 29.6 & 27.4 & 24.8 & 25.0 & 44.3 & 65.5 & 97.4 \\
Greece & 94.0 & 103.4 & 103.7 & 101.7 & 97.4 & 98.9 & 100.3 & 106.1 & 105.0 & 110.3 & 126.8 & 140.2 \\
Spain & 62.3 & 59.3 & 55.5 & 52.5 & 48.7 & 46.2 & 43.0 & 39.6 & 36.1 & 39.8 & 53.2 & 64.4 \\
France & 58.8 & 57.3 & 56.9 & 58.8 & 62.9 & 64.9 & 66.4 & 63.7 & 63.8 & 67.5 & 78.1 & 83.0 \\
Italy & 113.7 & 109.2 & 108.8 & 105.7 & 104.4 & 103.8 & 105.8 & 106.6 & 103.6 & 106.3 & 116.0 & 118.9 \\
Cyprus & 51.8 & 48.7 & 52.1 & 64.6 & 68.9 & 70.2 & 69.1 & 64.6 & 58.3 & 48.3 & 58.0 & 62.2 \\
Luxembourg & 6.4 & 6.2 & 6.3 & 6.3 & 6.1 & 6.3 & 6.1 & 6.7 & 6.7 & 13.6 & 14.5 & 18.2 \\
Malta & 57.1 & 55.9 & 62.1 & 60.1 & 69.3 & 72.2 & 69.9 & 63.4 & 61.7 & 63.1 & 68.6 & 70.4 \\
Netherlands & 61.1 & 53.8 & 50.7 & 50.5 & 52.0 & 52.4 & 51.8 & 47.4 & 45.3 & 58.2 & 60.8 & 64.8 \\
Austria & 67.2 & 66.5 & 67.1 & 66.5 & 65.5 & 64.8 & 63.9 & 62.1 & 59.3 & 62.5 & 67.5 & 70.4 \\
Portugal & 49.6 & 48.7 & 51.0 & 53.7 & 55.1 & 56.5 & 61.7 & 63.9 & 62.7 & 65.3 & 76.1 & 82.8 \\
Slovenia & 23.9 & 26.8 & 26.8 & 28.0 & 27.5 & 27.2 & 27.0 & 26.7 & 23.4 & 22.5 & 35.4 & 40.7 \\
Slovakia & 47.8 & 50.3 & 48.9 & 43.4 & 42.4 & 41.5 & 34.2 & 30.5 & 29.6 & 27.8 & 35.4 & 42.1 \\
Finland & 45.7 & 43.8 & 42.5 & 41.5 & 44.5 & 44.4 & 41.7 & 39.7 & 35.2 & 34.1 & 43.8 & 49.0 \\
Euro area & 71.7 & 69.2 & 68.1 & 67.9 & 69.0 & 69.4 & 70.0 & 68.4 & 66.0 & 69.7 & 79.1 & 84.1 \\
\hline
\end{tabular}

Note: Based on The crisis of European Monetary Union - Lessons to be drawn, Issing, 2011, Journal of Policy Modeling, 33(5), p. 737-749.

Table 2

Government budget balance (as \% of GDP) in the euro area countries

\begin{tabular}{|c|c|c|c|c|c|c|c|c|c|c|c|c|}
\hline & 1999 & 2000 & 2001 & 2002 & 2003 & 2004 & 2005 & 2006 & 2007 & 2008 & 2009 & $\begin{array}{l}\text { EC } \\
2010\end{array}$ \\
\hline Belgium & -0.6 & 0.0 & 0.4 & -0.1 & -0.1 & -0.3 & -2.8 & 0.2 & -0.3 & -1.3 & -6.0 & -4.8 \\
\hline Gemmany & -1.5 & 1.3 & -2.8 & -3.7 & -4.0 & -3.8 & -3.3 & -1.6 & 0.3 & 0.1 & -3.0 & -3.7 \\
\hline Estonia & -3.5 & -0.2 & -0.1 & 0.3 & 1.7 & 1.6 & 1.6 & 2.4 & 2.5 & -2.8 & -1.7 & -1.0 \\
\hline Ireland & 2.7 & 4.7 & 0.9 & -0.3 & 0.4 & 1.4 & 1.6 & 2.9 & 0.0 & -7.3 & -14.4 & -32.3 \\
\hline Greece & -3.1 & -3.7 & -4.5 & -4.8 & -5.6 & -7.5 & -5.2 & -5.7 & -6.4 & -9.4 & -15.4 & -9.6 \\
\hline Spain & -1.4 & -1.0 & -0.6 & -0.5 & -0.2 & -0.3 & 1.0 & 2.0 & 1.9 & -4.2 & -11.1 & -9.3 \\
\hline France & -1.8 & -1.5 & -1.5 & -3.1 & -4.1 & -3.6 & -2.9 & -2.3 & -2.7 & -3.3 & -7.5 & -7.7 \\
\hline Italy & -1.7 & -0.8 & -3.1 & -2.9 & -3.5 & -3.5 & -4.3 & -3.4 & -1.5 & -2.7 & -5.3 & -5.0 \\
\hline Cyprus & -4.3 & -2.3 & -2.2 & -4.4 & -6.5 & -4.1 & -2.4 & -1.2 & 3.4 & 0.9 & -6.0 & -5.9 \\
\hline Luxembourg & 3.4 & 6.0 & 6.1 & 2.1 & 0.5 & -1.1 & 0.0 & 1.4 & 3.7 & 3.0 & -0.7 & -1.8 \\
\hline Malta & -7.7 & -6.2 & -6.4 & -5.5 & -9.9 & -4.7 & -3.0 & -2.7 & -2.3 & -4.8 & -3.8 & -4.2 \\
\hline Netherlands & 0.4 & 2.0 & -0.2 & -2.1 & -3.1 & -1.7 & -0.3 & 0.5 & 0.2 & 0.6 & -5.4 & -5.8 \\
\hline Austria & -2.3 & -1.7 & 0.0 & -0.7 & -1.4 & -4.4 & -1.7 & -1.5 & -0.4 & -0.5 & -3.5 & -4.3 \\
\hline Portugal & -2.7 & -2.9 & -4.3 & -2.9 & -3.0 & -3.4 & -5.9 & -4.1 & -2.8 & -2.9 & -9.3 & -7.3 \\
\hline Slovenia & -3.0 & -3.7 & -4.0 & -2.5 & -2.7 & -2.2 & -1.4 & -1.3 & 0.0 & -1.8 & -5.8 & -5.8 \\
\hline Slovakia & -7.4 & -12.3 & -6.5 & -8.2 & -2.8 & -2.4 & -2.8 & -3.2 & -1.8 & -2.1 & -7.9 & -8.2 \\
\hline Finland & 1.6 & 6.8 & 5.0 & 4.0 & 2.4 & 2.3 & 2.7 & 4.0 & 5.2 & 4.2 & -2.5 & -3.1 \\
\hline Euro area & -1.4 & 0.0 & -1.9 & -2.6 & -3.1 & -2.9 & -2.5 & -1.4 & -0.6 & -2.0 & -6.3 & -6.3 \\
\hline
\end{tabular}

Note: Based on The crisis of European Monetary Union - Lessons to be drawn, Issing, 2011, Journal of Policy Modeling, 33(5), p. 737-749. 
Table 3

Unit labour cost growth across euro area countries (annual \% changes)

\begin{tabular}{llrrrrrrr}
\hline & Average 1999-2009 & 2007 & 2008 & 2009 & 2009 Q4 & 2010 Q1 & 2010 Q2 & 2010 Q3 \\
\hline Germany & 0.7 & -0.1 & 2.4 & 5.2 & 1.9 & -0.4 & -1.2 & -0.9 \\
France & 2.0 & 1.5 & 2.9 & 3.0 & 1.3 & 0.9 & 1.1 & 0.9 \\
Italy & 2.8 & 1.9 & 4.5 & 4.3 & 0.8 & -1.7 & -0.8 & -0.9 \\
Spain & 3.0 & 4.0 & 4.9 & 0.8 & 0.0 & -0.7 & -1.0 & -1.5 \\
Netherlands & 2.4 & 1.6 & 2.9 & 5.2 & 2.4 & -1.2 & -2.1 & \\
Belgium & 2.1 & 2.1 & 4.4 & 4.3 & 0.3 & -1.4 & -0.8 & 0.2 \\
Austria & 1.2 & 1.1 & 2.8 & 5.0 & 2.9 & 1.4 & -0.3 & -0.4 \\
Greece & 3.6 & 3.7 & 5.7 & 3.9 & 3.3 & -3.9 & -1.4 & -1.3 \\
Ireland & 3.0 & 3.4 & 5.9 & -0.6 & -2.0 & -5.6 & -2.6 & -5.5 \\
Finland & 2.1 & 0.5 & 5.8 & 7.7 & 3.6 & -1.5 & -3.5 & -1.4 \\
Portugal & 2.8 & 1.2 & 3.1 & 3.5 & 1.7 & -0.5 & -0.5 & 0.1 \\
Slovakia & 4.1 & 0.2 & 4.0 & 7.5 & 4.5 & -4.2 & -4.0 & -3.2 \\
Luxembourg & 2.9 & 1.6 & 5.5 & 6.7 & 0.7 & 0.7 & -2.4 & 0.7 \\
Slovenia & 4.9 & 2.6 & 5.9 & 8.5 & 4.8 & 0.2 & 0.4 & 1.3 \\
Cyprus & 2.8 & 1.1 & 1.5 & 4.3 & 5.0 & 2.0 & -0.1 & 0.6 \\
Malta & 3.1 & 0.8 & 4.0 & 4.0 & -0.7 & -4.7 & -1.8 & -0.3 \\
Estonia & 6.2 & 17.4 & 16.3 & 1.1 & -8.2 & -9.7 & -10.1 & -8.5 \\
Euro area & 1.9 & 1.5 & 3.5 & 3.9 & 1.4 & -0.5 & -0.6 & -0.5 \\
\hline
\end{tabular}

Note: Based on The crisis of European Monetary Union - Lessons to be drawn, Issing, 2011, Journal of Policy Modeling, 33(5), p. 737-749.

Table 4

Balance of payments: current accounts balances across euro area countries (\% change over previous period)

\begin{tabular}{lcrrrrrrr}
\hline & Average & 2007 & 2008 & 2009 & \multicolumn{7}{c}{ Average over last four quarters ${ }^{b}$} \\
& $1999-2009^{\mathrm{a}}$ & & & & 2009 Q4 & $2010 \mathrm{Q1}$ & 2010 Q12 & 2010 ( \\
\hline Germany & 3.3 & 7.6 & 6.7 & 4.9 & 4.9 & 5.2 & 5.3 & 5.4 \\
France & 0.1 & -1.0 & -1.9 & -1.9 & -1.9 & -1.9 & -1.7 & -2.0 \\
Italy & -1.5 & -2.4 & -3.4 & -3.2 & -3.2 & -3.1 & -3.1 & -3.3 \\
Spain & -5.9 & -10.0 & -9.7 & -5.5 & -5.5 & -5.0 & -5.1 & -5.0 \\
Netherlands & 5.6 & 7.2 & 4.9 & 5.2 & 5.2 & 6.1 & 6.0 & 6.7 \\
Belgium & 4.0 & 1.6 & -1.9 & 0.8 & 0.8 & 0.8 & 1.1 & 1.1 \\
Austria & - & - & - & - & - & - & - & - \\
Greece & -9.2 & -14.5 & -14.8 & -11.1 & -11.1 & -12.2 & -11.2 & -11.0 \\
Ireland & -2.1 & -5.3 & -5.6 & -3.0 & -3.0 & -2.4 & -2.2 & -1.6 \\
Finland & 5.4 & 4.3 & 2.9 & 2.7 & 2.7 & 2.6 & 2.8 & 2.8 \\
Portugal & -9.1 & -10.1 & -12.6 & -10.3 & -10.3 & -9.7 & -10.3 & -9.7 \\
Slovakia & - & -5.3 & -6.6 & -3.2 & -3.2 & -2.6 & -2.6 & -3.5 \\
Luxembourg & 11.3 & 10.1 & 5.3 & 6.7 & 6.7 & 6.5 & 8.3 & 9.1 \\
Slovenia & -2.4 & -4.7 & -6.7 & -1.5 & -1.5 & -1.0 & -1.3 & -0.4 \\
Cyprus & -9.0 & -11.7 & -17.2 & -7.5 & -7.5 & -8.3 & -1.6 & -4.3 \\
Malta & -5.7 & -6.2 & -5.6 & -6.1 & - & - & - & - \\
Estonia & -8.7 & -17.2 & -9.7 & 4.5 & 4.5 & 4.8 & 4.1 & 3.7 \\
Euro area & -0.2 & 0.1 & -1.4 & -0.6 & -0.6 & -0.4 & -0.3 & -0.4 \\
\hline
\end{tabular}

Note: Based on The crisis of European Monetary Union - Lessons to be drawn, Issing, 2011, Journal of Policy Modeling, 33(5), p. 737-749. 
The European economic crisis is of such a size that forces us to ask new questions and rethink the answers to old questions. Relying on the differences pointed out by Donald Rumsfeld, we can talk about "known unknowns" and "unknown unknowns" of the EMU. The first thing everyone knew was that the countries participating in the EMU were not identical. At the time of entry they had significant structural differences (in terms of, for example, their level of development, specialization and labor market institutions) and had different macroeconomic history, especially in terms of inflation and exchange rate. Compared to the U.S., the EMU is characterized by greater asymmetry between countries (particularly peripheral countries) and can rely on weaker adjustment mechanisms (especially because of the low labor mobility and the absence of risk sharing arrangements). The EMU is essentially based on an independent central bank oriented to price stability and commitment to budgetary discipline. The EMU was conceived as an economic and monetary union, and not as a financial union. While public debt in southern countries has remained stable or even fell during the first decade, private debt financed by capital inflows has increased, which has led to massive macroeconomic divergences. At the end of 2009 , the answer to the crisis was developed on three fronts. First, the focus was on development of instruments for crisis management. Second, the fiscal regime has been put back onto the drawing board. Third, the need for systemic reform has been recognized (Pisani- Ferry, 2013). The future of the euro zone depends on the efficiency of institutional reforms at the EU level and economic reforms in some countries (including deep reforms of public finances). It is very important to take into account the changes in the EU functioning philosophy (Bukowski, 2011).

\section{CONCLUSION}

The biggest off all achievements in the European integration processes is represented by EMU. The EMU contributes both symbolically and practically to the formation of a single, democratic Europe, where national differences are constructively agreed, and within them exist the free movement of people, commodity and investments. The EMU is a developmental method of coexistent monetary arrangement without contradictions in Europe. It implies common monetary policy, common currency, euro and coordination between economic and financial policy. Being an EMU member is of an immense significance for each member state. The following advantages are the most important: transaction cost reduction, euro as the single currency, reduction of exchange rate fluctuation risk, single market, bigger price transparency, prevention of competitive devaluation and speculation. All these advantages have its own implication on trade in the Eurozone. Firstly, transaction cost reduction enables easier and more profitable trade within the EMU member states. Secondly, the 
euro, as the single currency, ensures completely integrated European market, and stimulates trade among the Eurozone countries and the rest of the world. Next, elimination of exchange rate fluctuation risk stimulates international trade and international investments. Furthermore, high level of price transparency stimulates trade within the EMU and it also stimulates economic efficiency within the Eurozone. Lastly, common monetary policy and the single currency enable prevention of furher competitive devaluations and speculations. It can be concluded that, the great number of advantages realized as being an EMU member make Eurozone the best trade power in the world. The global economic crisis has had a significant impact on the euro and the European Monetary Union. It should be emphasized that the single currency would act as a powerful driver of convergence, and that the trade creation effect leads to a greater degree of harmonization of business cycles, which would facilitate the achievement of the objectives of monetary policy. The future of the EMU will depend on the implementation of comprehensive economic reforms in member states, which should be directed to radical systemic change.

\section{REFERENCES}

Beetsma, R., \& Giuliodori, M. (2010). The Macroeconomic Costs and Benefits of the EMU and Other Monetary Unions: An Overview of Recent Research. Journal of Economic Literature, 48(3), 603-641.

Bukowski, S.I. (2011). Economic and Monetary Union-current fiscal disturbances and the future. International Advances in Economic Research, 17(3), 274-287.

Cooper, L., \& Tomic, A. (2007). European monetary union (EMU) and the single currency: its current status. Journal of International Business Research, 6(2), 59-68.

De Grauwe, P. (2010). The Greek crisis and the future of the eurozone. Intereconomics, 89-93.

Dunn, R. (1999). An easy monetary policy in the European union. Challenge, 42(4), 29 - 43.

Džombić, I. (2010). Evropska unija - prošlost, sadašnjost, budućnost. Sarajevo: Friedrich- Ebert-Stiftung.

Eudey, G. (1998). Why Is Europe Forming A Monetary Union. Federal Reserve Bank of Philadelphia Business Review, 13-21.

European Commission. Economic and Financial Affairs, Economic and Monetary Union. Retrieved from

http://ec.europa.eu/economy_finance/euro/emu/index_en.htm 2012 Nov 28. 
45 | THE ADVANTAGES OF BEING A MEMBER OF THE EUROPEAN MONETARY UNION AND ITS INFLUENCE ON TRADE IN THE EUROZONE

European Union. Economic and monetary affairs. Retrieved from http://europa.eu/pol/emu/index en.htm 2012 Nov 28.

Issing, O. (2011). The crisis of European Monetary Union-Lessons to be drawn. Journal of Policy Modeling, 33(5), 737-749.

Kösters, W. (2010). Challenges Facing European Monetary Union-Rules and Assignment or Discretion and Coordination. Intereconomics, 45(2), 8689.

Kotilainen, M. (1992). The Benefits and Costs of EMU. Unitas, 64(3), 8.

Memišević, S. (2010). Monetarno okrupnjavanje na evropskom tlu - Ekonomska i monetarna unija. Sarajevo: Direkcija za evropske integracije.

Miljković, D. (2008). Međunarodne finansije. Beograd: Centar za izdavačku delatnost Ekonomskog fakulteta.

Mucha-Leszko, B., \& Kakol, M. (2009). Will the financial-economic crisis of 2008-2009 accelerate monetary integration in the EU. Eurolimes, 8, 180181.

Neu, R. (2000). European monetary union: Will it really contribute to stability. Business Economics, 35(1), 59-62.

Perry, S. (1994). European Monetary Union: What happens next. Financial Management, 72(10), 58.

Pisani-Ferry, J. (2013). The known unknowns and unknown unknowns of European Monetary Union. Journal of International Money and Finance, 34, 6-14.

Salvatore, D. (2009). Euro. Princeton University Press.

Siklos, P. (2009). European Monetary Union. Princeton University Press.

Stanek, M.B. (2001). International monetary arrangements: the European Union and the euro. European Business Review, 13(5), 279-291. doi:10.1108/EUM0000000005796

Tavlas, G. (2004). Benefits and costs of entering the eurozone. Cato Journal, 24(1-2), 89-106.

The University of North Carolina. Euro Economics, Costs and Benefits of Joining a Monetary Union. Retrieved from http://www.unc.edu/depts/europe/euroeconomics/Cost\%20Benefit.php 2012 Dec 12. 
The University of North Carolina. The Costs and Benefits of the Euro In European Monetary Union Countries. Retrieved from http://www.unc.edu/ salemi/Econ006/Portone_2004.pdf 2012 Dec 12.

van Veen, T. (2002). European Economic and Monetary Integration and the Euro. Australian Economic Review,35(4), 455-462. doi:10.1111/14678462.00262

Zirojević, M., \& Jelisavac, S. (2002). Evropska monetarna unija i evro. Međunarodni problemi, 54(1-2), 99-114.

Primljeno: 14.06.2013. Odobreno: 14.08.2013. 